\title{
Anthropogeographical Investigations in British New Guinea (Continued)
}

Author(s): C. G. Seligmann and W. Mersh Strong

Source: The Geographical Journal, Vol. 27, No. 4 (Apr., 1906), pp. 347-365

Published by: geographicalj

Stable URL: http://www.jstor.org/stable/1776235

Accessed: 27-06-2016 09:57 UTC

\section{Your use of the JSTOR archive indicates your acceptance of the Terms \& Conditions of Use, available at}

http://about.jstor.org/terms

JSTOR is a not-for-profit service that helps scholars, researchers, and students discover, use, and build upon a wide range of content in a trusted digital archive. We use information technology and tools to increase productivity and facilitate new forms of scholarship. For more information about JSTOR, please contact support@jstor.org.

The Royal Geographical Society (with the Institute of British Geographers), Wiley are collaborating with JSTOR to digitize, preserve and extend access to The Geographical Journal 
Colonel H. W. Feilden, who was unable to attend, sends the following remarks on Mr. MacIver's paper: My personal acquaintance with the ruins of Rhodesia is confinfd to those of Khami, near Bulawayo. I visited them last year. These buildings do not seem to me beyond the intelligence of native African tribes to construct. At the same time, is it not hazardous to deny that those who built these "cities" were not influenced by an ingraft of a bigher civilization from without? Do we not possibly underrate the traffics and discoveries of the ancients, and the influence they may have exerted by contact with the barbarous inhabitants of South Africa? But my object in joining in this discussion is to draw attention to facts which seem to have been overlooked, or touched on very lightly. The enormous débris mounds, covering many acres, surrounding the ruins of $\mathrm{Khami}$, have been raised by a people largely using stone. Implements of stone, such as flakes and cores, are to be met with in thousands ; in fact, hardly a stone I picked up, even on the surface of the débris mounds, failed to show the handiwork of man. This suggests that the inhabitants of Khami could not have been in a very forward condition of civilization.

I do not suggest that the presence of a partially stone-using population necessarily entails remoteness in time for the building of Khami. I find without doubt that a stone-using people of Bushman-Hottentot character lived on the shores of Table bay and False bay at the time of the first occupation by the Dutch. In their kitchen middens, relics of European wares are mixed with the stone implements of the chase and of their daily use. These stone implements are Neolithic in type ; so are those at Khami. There is a Palæolithic and Neolithic period observable in the Stone Age of South Africa. I am not prepared as yet to draw a line of demarcation between these periods; probably they inosculate. A great lapse of time must have elapsed between the Palæolithic race, which has left abundant traces of its workmanship in the high-level river gravels of the Zambezi valley, deposited before the Victoria falls and the chasms of that river were carved out, and the builders of Khami. I have ventured to draw attention to the stone-using character of the people who raised the débris mounds of Khami, in the hope that the future explorers of the ruins of Rhodesia may pay greater attention than has hitherto been done to this interesting and perhaps elucidating subject.

\section{ANTHROPOGEOGRAPHICAL INVESTIGATIONS IN BRITISH NEW GUINEA.*}

\section{By C. G. SELIGMANN, M.B., M.R.C.P., and W. MERSH STRONG,} M.A., M.D.

From the Alcesters we sailed to Murua, where at Bonagai there are some hundreds of feet of coral rock. Beneath this in places is a bluish rock. From this rock, when it has become altered and softened often

* Continued from p. 242. After the first part of this paper had appeared in print, I received a note from Dr. Strong, in which he states that-

(1) The mountains called the 'Tully peaks in his map of the Mekeo and Inauvorene districts (published in the March number of the Journal) are probably incorrectly named.

(2) On comparing the barometer used on his trip with the boiling-point thermometer, the former was found to be much in error, so that all heights are incorrect.C. G. S. 
to about the consistency of mud, gold is obtained. Some 7 miles from Wanai bay, where we anchored, proceeding towards Mapas island, the hills tumbling to the shore consist of several hundred feet of a bluish dolomitic limestone, fretted everywhere into pinnacles, and carrying only a flora of scrub and small trees. This was the site of a number of not very recent cliff burials, and we found a large number of bones, often placed in pots deposited in the shallow caves and limestone fissures. A few of the bones were painted red, and one skull had a pair of turtle-shell earrings slipped on to its zygomata.

Mapas island, over which towers Suloga peak, lies some 7 miles to the east of that site of these cliff-burials, and here, in the position

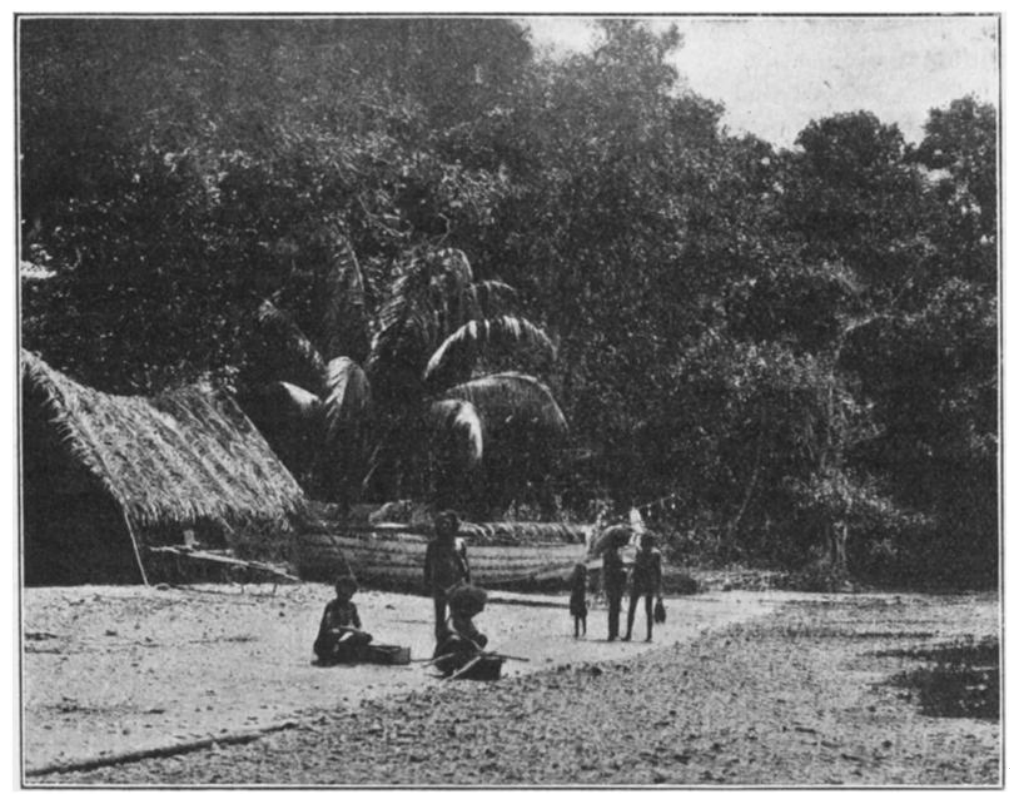

SULOGA VILLAGE. BEACH COMPOSED ALMOST ENTIRELY OF FLAKES.

indicated on the sketch, we come upon a portion of the sand beach covered inches thick with flakes and chips, a residue which only generations of stone-working could have produced. Here we made our camp, beside the two-house hamlet which is all that now remains of the two formerly prosperous and popular Suloga villages. Inquiries showed that the quarry lay somewhere on the seaward flank of Suloga hill, though it was by no means easy to find an adequate guide.

On leaving the beach the track led across half a mile of flat land, behind the mangrove belt, only a little elevated above the sea-level, thickly bushed, and with some great gaping red wounds where alluvial gold-mining was being carried on in the iron-impregnated soil. "Float" 
and doubtful outcrops of a stone clcsely resembling the common implement material were plentiful as we climbed. The rise was sharp and fairly even till, after a stiff scramble, the crest of Coconut hill (Wanakwaiin of the natives) was reached. This is a continuation of Suloga peak. Here, at an elevation of about 700 feet, was a natural clearing, one of those curious places, common in New Guinea, where trees do not grow, and from it Suloga harbour and the coast to the eastward lay map-wise below us.

This open space was some acres in extent and marshy, with plenty of chips lying about, and two remarkable standing stones of which we could

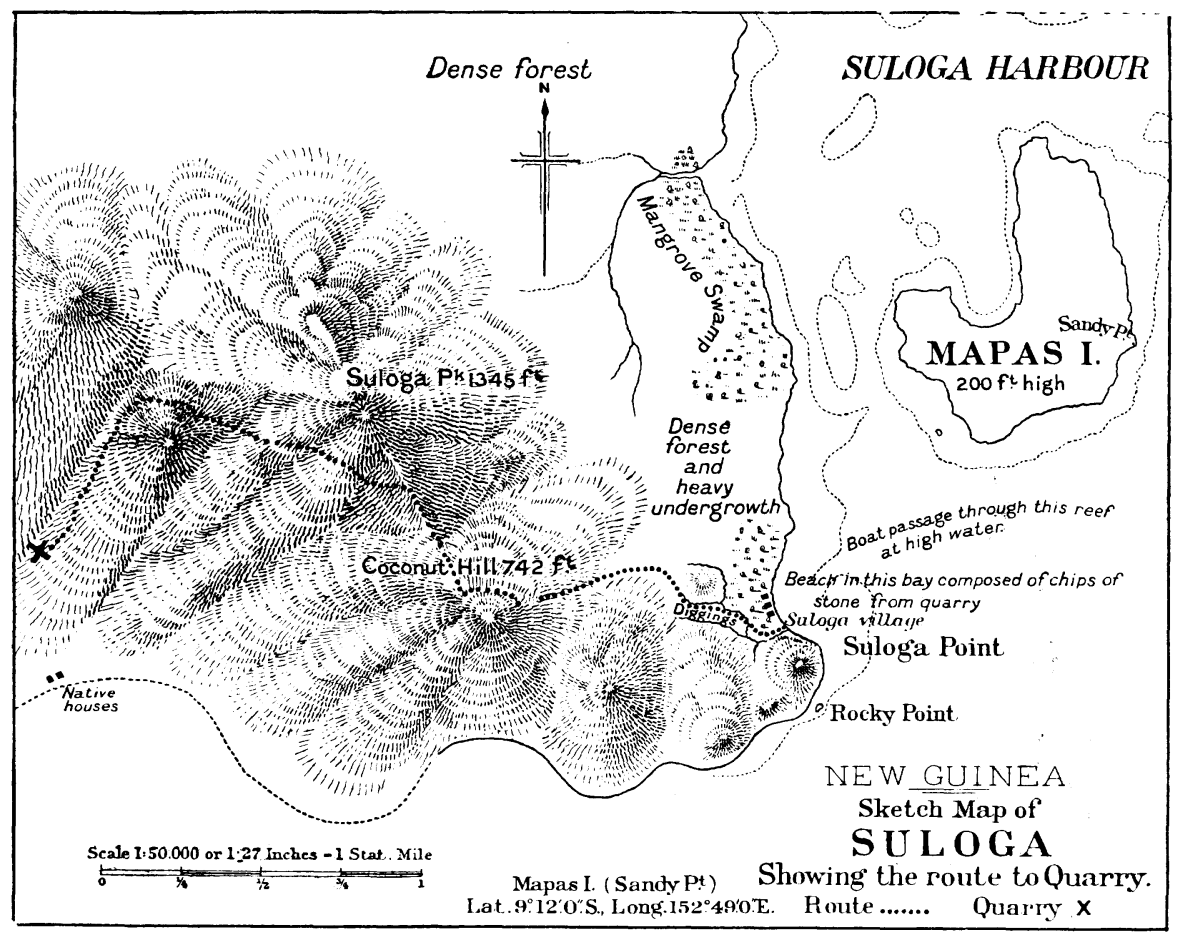

get no explanation. The bush on the opposite sides of this open space was, in the childhood of men now old, occupied by two large villagesWandari to the north, and Maied to the south-whose folk in the old times had been the custodians of the "quarry," and through whose hands its output passed. They chipped stones into rough shape, and bartered these (for there was a large trade in the unfinished article), or wrought them to laborious perfection on grindstones of graniticlooking rock, which we found lying along the track near their former dwelling-places. The largest are great blocks, some well over a hundredweight, with deep saucer-shaped depressions where the grinding 
had worn them down. The whole hill is deserted now, and the old village sites thickly covered with young jungle. About thirty years ago an epidemic swept the villages nearly clean, and with the dead died the art of making stone implements. The few survivors fled to the present two-house beach village of Suloga, or, by one account, went first to the other side of the bay, and later came back to their present position.

From the natural clearing on Coconut hill we walked north along the crest of the ridge through a few bundred yards of second-growth bush, where lay the old site of Maied village. Here stone chips were plentiful, and among them many stone implements in the earlier stages of manufacture, together with a few further advanced, but we found

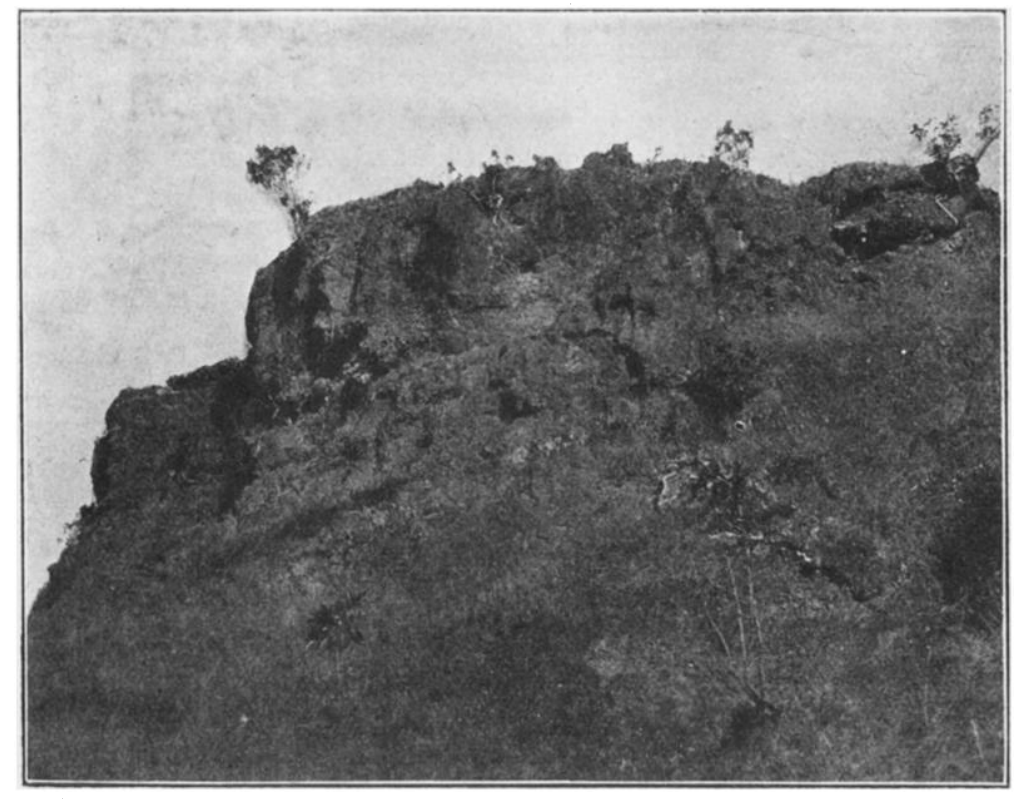

A PORTION OF THE OLD REEF FACE EXPOSED ON THE HILLSIDE TO THE WEST OF BARTLE BAT.

no finished or nearly finished tools or benam. Beyond was another strip of open country, rising sharply to the crest of Suloga peak, which is itself covered with heavy bush. This open space was sparsely grassed, the soil being a red sandy clay, above which protruded many detached boulders and what appeared to be true outcrops of rock apparently identical with the material from which stone implements were commonly made. Flakes lay everywhere, literally acres of flakes; not scattered specimens, but in compact sheets having a thickness measurable at least in inches-plain evidence of a vast amount of work extending over a considerable period of time. 
Soon we bore to the left, plunging into the thick bush of the peak's western face, and following a most fallible native guide; who led us far and near over ledges of volcanic rock and tumbled boulders, till at last, after a long rugged traverse of the mountain's flank, we came to the place of our desire. The steep slope breaks away suddenly in a half-circle 100 yards wide and perhaps 30 yards deep, down whose

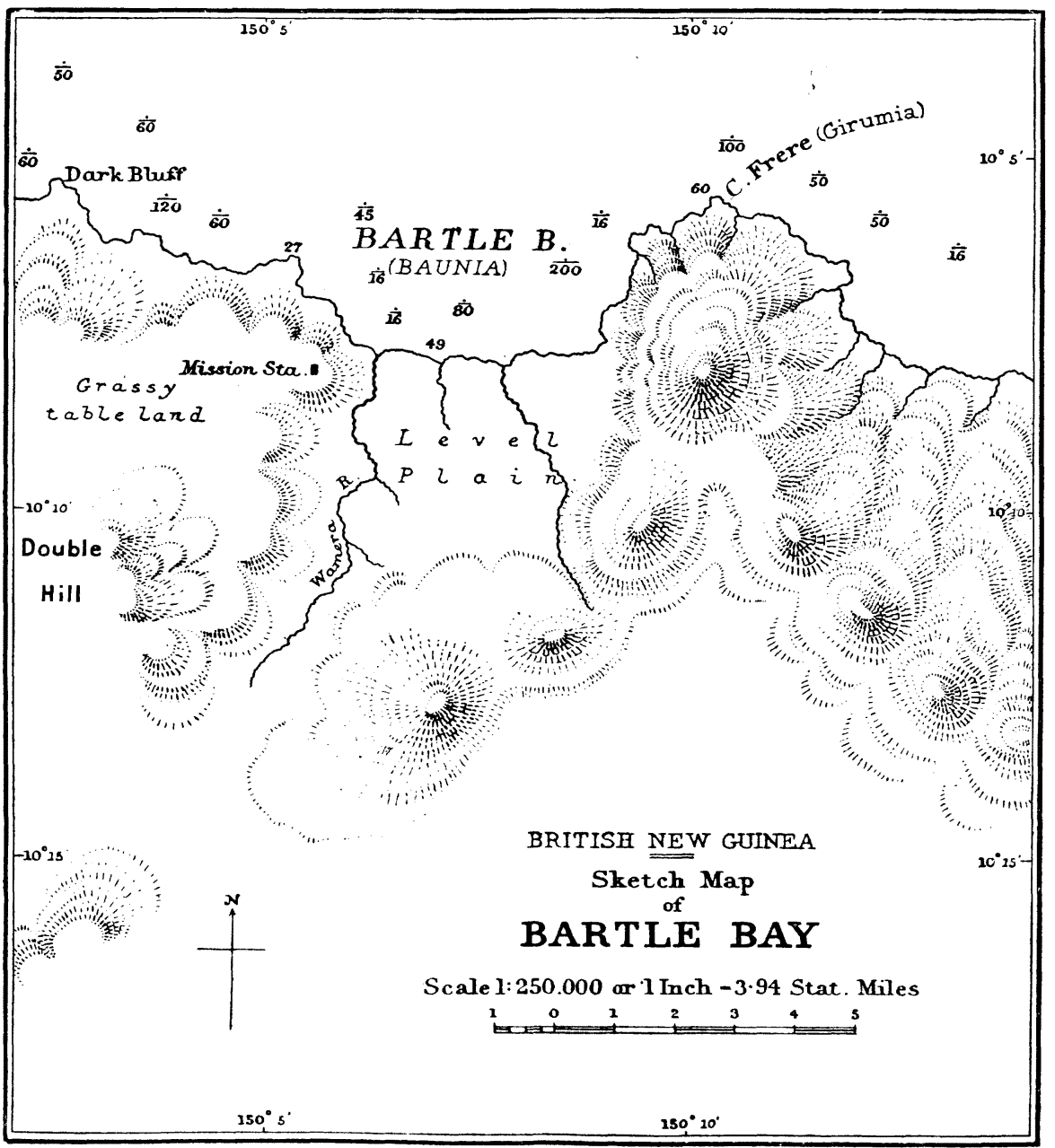

nearly perpendicular sides we scrambled to a creek-bed all houlders and ledges of tool stone, and showing frequently the curious narrow streaks and bands of lighter-coloured material which, running lengthwise of its blade, give the perfect benam its last attribute of value and beauty in the natives' eyes.

No doubt stone was taken everywhere from along this creek; but 
we had to follow its course down to an elevation of probably not more than 250 to 300 feet above the sea, and scarcely half a mile inland, before the traditionally most important place was reached. Here the little stream raced for more than a hundred yards in a trough formed by two remarkable rock masses. A smooth table of tool stone quite 25 feet wide was canted downhill at an angle of about $15^{\circ}$, and also tilted to the left at an angle of $25^{\circ}$ from the horizontal. Its upper edge is bordered by the jungle; its lower edge meets and fuses with a straight smooth cliff of the same rock, some 18 feet high, with a slightly undercut base which rises nearly at right angles to the table-shaped stone. At the foot of this cliff for its whole length runs a.series of bands, some very narrow and others several inches wide, of the lighter-coloured material.

There was no evidence anywhere of quarrying in the proper sense of that word. The descriptions we were able to gather of old-time methods of work gave no hint of anything of the sort; and the extreme hardness of the stone makes the idea at least prima faciê unlikely.* Furthermore, no real quarrying was in the least necessary, for the creek's bed just above the ledge is still full of broken pieces of beautifully marked stone, quite manageable in size, which the natives said used to be broken into workable fragments by dropping one upon another from as high as a man might lift. A further supply of material is found along the creek's right bank, where, butting on the edge of the table rock, are a number of rather compact masses of smaller stones, so curiously shaped and placed that for a time it seemed that they might be, as the natives said, implements in their very earliest state together with large flakes and cores. A closer examination of these beaps made it plain that, while a few of the surface stones might be artifacts, the bulk were the natural product, still in situ, of weathering, or of some fairly recent movement of the hillside's upper débris.

The table rock, and the cliff bounding it on the left, both end suddenly in a terraced drop of some 50 feet; after which the character of the valley, and especially of the sections cut by the stream, is so changed that a different geological formation seems to intervene. There was not time to go further down-stream than the lip of this fall; and it was while returning from examining it, and at a place where the surface soil had fallen away, that a mass of stones was seen similar to those butting on the table rock higher up, but in this case presenting clear evidence of having been produced in situ by natural causes.

The day after visiting the quarry was spent in collecting such information as is now obtainable about the disused quarry and the lost

* Sir William MacGregor, who visited the quarry, states, "They [the natives] break out stone, and it is said also split up the' rock, by fire" ('British New Guinea and its People,' p. 12. London : 1897). 
art of stone-working. The first breaking of the stone seems to have been a very chance affair, when pieces already broken by natural causes to some nearly suitable shape were not found ready to hand. The ultimate shape of the implement, whether it was to be adze, chisel, or benam, though it depended greatly on the workman's skill in cleaving, was undoubtedly assisted by the careful selection of a not too unkindly fragment to work upon. It is evident from this how it was that really choice benam, properly broad and thin and well marked, got part of their value from rarity of material- that is, from the scarcity of suitably shaped rough stones. For to make a benam from even the most promising bit of material must have required great perseverance and labour, while to have made one from a frankly unsympathetic beginning would be an appalling task even for Papuan patience and skill. The actual flaking is alleged to have been done with spherical water-worn stones about from 2 to 3 inches in diameter. These are found near Suloga, in what from the description one would guess was an old river-bed, and each consists, according to Mr. Fearnsides, of the core of a spheroid of gabroid dolomite.

Free flaking was the method by which implements were roughed out, the flakes occasionally being of such size and shape as to make a useful adze-blade when one edge was ground. After the tool had been carefully roughed out came the grinding, which at Murua was done on flat slabs of a granite-like rock found plentifully about Suloga and elsewhere in Murua. A slab of suitable size and shape was brought to the village from wherever it might be found, but no quarrying or serious trimming was attempted, and it was a case of finding the proper thing ready-made. Sand and water were used for all grinding, but the very last-the polishing-was done with water alone, the powder worn from the two stones then forming the "tooth."

Of ancient grindstones we found some dozen in all, but without making any determined search; some on or near the sites of the two former hill villages, some on the beach where the present Suloga village occupies ground on which a much larger settlement once existed. The depressions worn into all these grindstones were circular, going to show (as tradition also asserted) that the grinding motion was round and round rather than back and forth. Many unground stones were exported, notably to the Marshall Bennet and Trobriand groups, perhaps also to the D'Entrecasteaux and Louisiades. These would then be polished locally by their new owners, who, however, failed to obtain the beautiful even polish present on the best Murua-ground stones.

Dr. Marr and Mr. Fearnsides have examined a number of flakes and rough and polished adzes derived from Murua and the Marshall Bennet group, as well as a number of adze-heads collected in the Central Division and traditionally derived from further east. The stone implements obtained at Murua fall geologically into two series- 
(1) Those composed of an ash often banded, and always more or less silicified.

(2) Those composed of lava showing well-marked flow structure (rhyolite), and containing inclusions, the latter giving rise to the lighter bands.

To the first division belong a number of flakes found at Wanai bay, at a spot locally known as "Red-bluff," as well as rough unground adze-blades picked up at different spots on the track leading towards Suloga peak from Coconut hill. An unpolished adze-head collected at Gawa also consists of silicified ash. To the second class belong a roughly flaked adze collected on the track to the peak, as well as flakes picked up on the grassy area below the peak and other flakes collected on Suloga beach, as do a series of Murua-made adze-blades obtained at Iwa.

It thus seems clear that two geologically distinct kinds of rock were worked at Murua, one being a volcanic ash, the other a lava. These might be expected to occur close together, or even to form superposed strata. Both rocks may be, and at times actually are, banded, and, both being hard, we did not, until this was pointed out by Dr. Marr, appreciate that there were at Murua two quite distinct kinds of rock from which adzes were made. Hence nothing can be said as to whether the natives had a preference for either kind of stone; but, judging from the adze-heads collected, the broadest and most even bands undoubtedly occur in the rhyolite, which would thus have come to be especially valued.

In old times Murua-made implements were common over a very large territory, being traded from tribe to tribe on the north-east coast of the mainland to Collingwood bay at least, and on the south-west certainly as far as the Papuan gulf, and quite possibly even beyond.* The introduction of iron, or rather its coming into general use, would necessarily put an end to the making of stone implements for actual work, but the ending, it would be expected, would be a gradual one. Yet the Suloga people, by their own account, suddenly stopped making adzes for both practical and ceremonial use. Said an old man, "My grandfather was a famous maker of stones, who taught his son, my father, whom as a small child I often saw at the work. Undoubtedly he would have taught me as I grew up, but for the big sickness. He died, and I was never taught, nor were any of my generation." And even if a synchrony of introduced iron and a devastating epidemic killed at a single blow the

* For the northern and western extension to Collingwood bay of the province of the Suloga adze, I am indebted to the kindness of Mr. A. M. Campbell, resident magistrate of the Eastern Division, who gave the expedition a beautifully banded adzeblade of Suloga rhyolite collected in Collingwood bay. With regard to the Papuan gulf, Dr. Marr, who has examined a small adze-head I obtained at Jokea, considers this to be composed of a silicified ash identical with that of which many of the Suloga adze-blades consist. 
art of making stones for use, there remains the problem of the implements not for use-the "ceremonial" benam, to give them the name by which they are known at Tubetube. These Murua-made benam had a range which spread through the south-eastern archipelagos, and extended in an easterly direction on the southern coast at least as far as Mullins harbour.

With armshells, benam which, though less than half an inch thick and exquisitely polished, might exceed 13 inches in length and 5 inches in breadth, formed the high denomination currency of the south-eastern archipelagos. Their provenance, so far as we know, was Murua only, with Suloga as the principal and perhaps only quarry, and also the chief factory for turning out the finished product. Iron, as already pointed out, may be supposed to have quickly destroyed the value of stone tools, and so killed, in perhaps a very short time, the art of making them; but benam still retain their ceremonial use, while their value, either as ornament or as currency, has certainly not diminished. They are worth more to-day than ever, and it is a mystery why their manufacture was abandoned as suddenly as appears unquestionably the case. The mere devastation by disease of the old Suloga villages is not enough to account for the sudden permanent cessation of benam-making by the survivors; since it appeared that benam were formerly made elsewhere on Murua, and perhaps even in other places among the islands from Murua stone imported in the rough. Grinding and polishing shell is still common enough everywhere throughout SouthEastern British New Guinea; but in this district the art of flaking, grinding, and polishing stone is extinct, and as loss and breakage and occasional export (but only very occasional now) make them rarer and rarer, the value of benam is rapidly increasing. The trader finds it worth while to pay from $£ 5$ to $£ 10$ in cash or in trade goods for a really good example, when he can secure one. He is sure to sell it again for a handsome profit in the course of his wanderings, taking in exchange copra, tortoise-shell, and other native produce, supposing he does not find it better worth while keeping for the prestige its mere possession brings.

Westwards and somewhat to the north of Murua lie the Marshall Bennet islands, Gawa, Kwaiawata, Dugumenu, and Iwa (Jouveney island). West of these, and distant but 9 miles from the Trobriands, is Kitava (Jurien island).

Dugumenu is described as a "low coral island about half a mile in diameter, covered by trees and coconuts." We did not visit it, as we were told at Gawa that it held no permanent population, but was rather of the nature of a coconut plantation for Gawa and Kwaiawata. The other islands of the group are all elevated atolls whose population live in hamlets in the central depression of the old lagoon bed, and there make their gardens out of sight of the sea, and marvellously sheltered 
from storms. On Gawa the villages in the old lagoon bed were some 60 feet below the uppermost edge of the encircling coral wall.

The edge of the reef at Iwa has been elevated to a height of about 350 feet at the south-east extremity of the island. In the case of Gawa and Kwaiawata, the reef is about 100 feet higher than this. Only the northern end of Kitava was examined, and here the reef rose to a height of about 300 feet. On examining the sections constructed by Captain Pim, it is clear that all the islands are more or less terraced. This did not appear to us to be entirely or almost entirely due to weathering, but rather to indicate successive periods of uplift. On Iwa the terracing was particularly marked, and the ascent easy after a short almost vertical portion of the cliff face above the beach had been ascended. All these islands, then, show a marked likeness to each other, and differ only in detail, so that a good general idea of the group can be obtained by carefully considering one island. 'To this end, Captain Pim's account of Kwaiawata is quoted at length.

“This island is small, roughly circular, its greatest diameter being about a mile. In places it is very steep to, but a fringing reef lies off the south-east and north-west sides, and a belt of gradually shoaling sand just outside the reef affords convenient anchorage. On the east and west points of the island the cliffs come right down to the water, and there are numerous small caves to be seen along these parts of the coast; apparently some of these caves are used by fishing parties to sleep in, as mats, etc., were found in them, and places where fires had been made and food cooked were seen. The beach is composed of coral cement, with loose coral boulders scattered about, and is about 6 or 7 feet above high-water mark.

"Starting from the beach on the east side, a gentle slope leads up to the first ridge (about 20 feet above sea-level), which appears to be an old sea-beach; a slight depression follows; and then, climbing up a sharp rise, the first platform, about 100 feet above the sea-level, is reached.

"This platform, a large portion of which is covered with heavy scrub timber, leads up to the foot of a wall-like cliff, only to be scaled by ladders made and placed in position by the natives.

" The top of the cliff is 240 feet high, and a winding path, running along the edge for some distance, leads to the crest of the old reef, 415 feet above sea-level. This is by no means the highest point of this side of the island, but rather bore the appearance of being, in the days when the surface of the reef was awash, a deep-water entrance into the lagoon.

" Numerous coral patches lay scattered about, and rose much higher than the place where we were standing when the reading of the barometer was taken. I should consider they were quite 30 to 40 feet above our level, and it was strange to see how well the coral had stood 
the destructive influence of the elements. I, who had passed most of my life among coral reefs, could almost fancy I was walking on one of the Queensland Barrier reefs as I looked round upon the boulders scattered about.

"From this spot we could see the floor of the old lagoon, which dipped towards the centre, giving a view of extensive gardens, with here and there a group of coconut and betel-nut palm towering above the low undergrowth, and drawing attention to the little brown houses of the native villages, whose sites they markerl, and around which they were clustered.

"The parts of the central depression not under cultivation are covered with a thick, heavy, second growth of young timber and ferns, in striking contrast to the higher, larger-girthed trees of the circumferential rim.

"Descending the slope, past numerous garden fences, we reached the centre of the lagoon, and found it to be 325 feet above sea-level. The soil was a rich, heavy vegetable mould, and in the villages and on the paths it was trodden into a compact mass as hard as cement, that held the water, and became so slippery with every shower of rain that it was positively dangerous to walk upon. Passing through a number of hamlets, the ground became higher and the coral boulders more numerous, until the inner edge of the old breaker was reached. The path led through a gully between two coral walls covered with high trees, and emerged at the top of a cliff which went down almost perpendicularly. The barometer showed the height to be 440 feet, and we were standing in a crevice between walls which were at least 20 or 30 feet higher. The crevice continued down the face of the cliff in a slanting direction, forming a chimney, down which the path led, and which the natives said was the only way to reach the flat below.

"Scrambling down the cliff, towards which it was necessary to keep one's face, shifting hands and feet slowly and carefully from one projecting coral point to another, was tedious and painful work. The projecting points of coral were worn smooth by the native feet constantly passing over them; a passing shower had made the coral as slippery as ice, and the occasional pools of water in the central depression of the island had not improved our boots for this kind of work, where to slip meant a fall of some hundreds of feet.

"About halfway down a slight projection afforded a much-needed rest, and we were met here by a group of native women, who were carrying up great bundles of coconuts, firewood, and food from their gardens below. Everything was carried up on the head, and it was wonderful to see the dexterity shown in balancing the load as they climbed up the steep track.

"A reading of the barometer gave the height here as 280 feet, and I am rather inclined to think at some time or other this was the water-

No. IV.-APRIL, 1906.] 
line of the reef, the coral above this line being most distinctly more weathered than that below it. Continuing the descent, the bottom of the cliff was found to be 90 feet above sea-level, and this also seemed to hare been a water-level at some time. From the foot of the cliff a gentle slope, covered with cultivation patches and thick scrub, fell away towards the water. A few small huts were seen on the edge of the

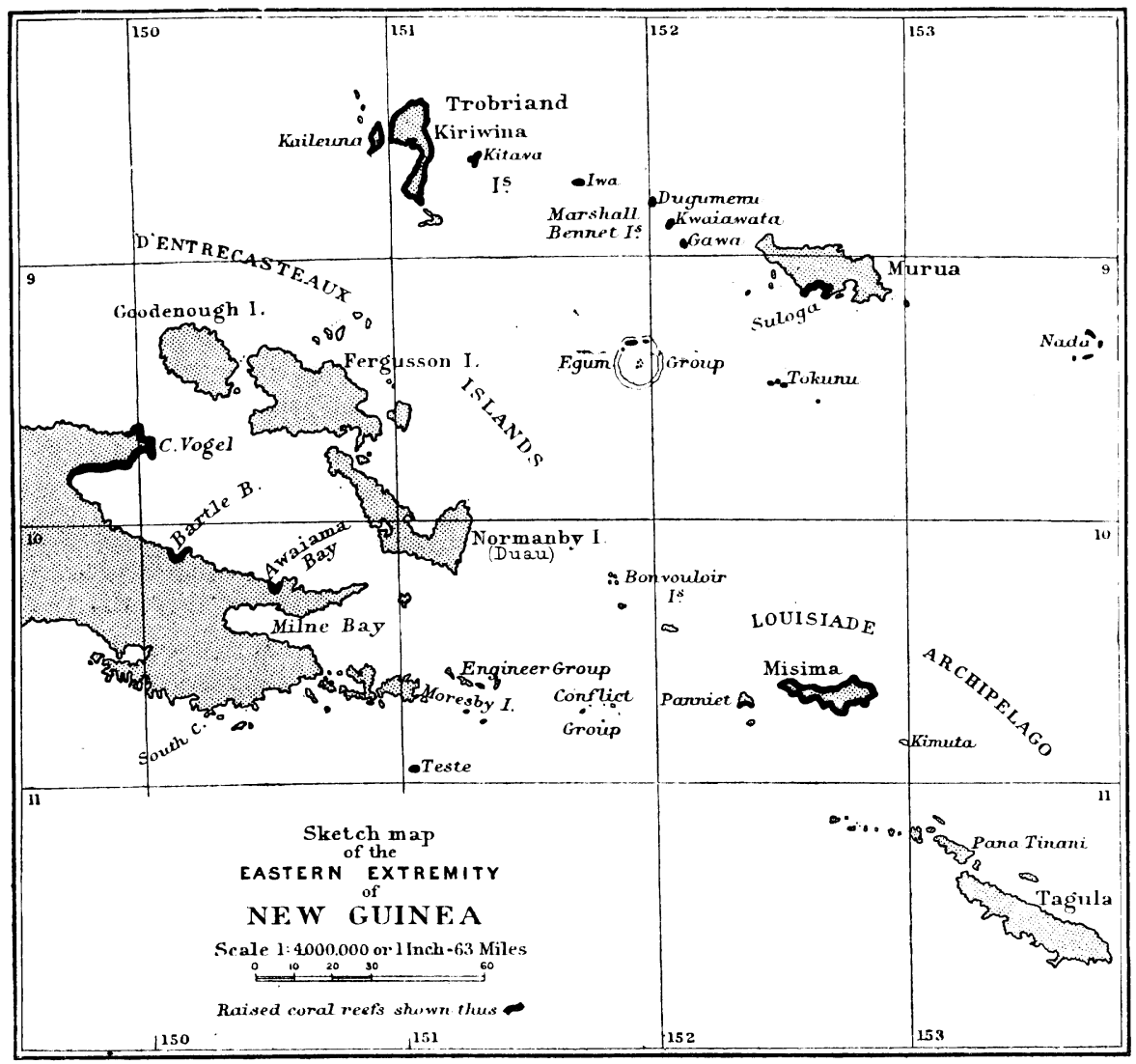

scrub, which we were told were used as living-bouses by people working in the gardens, or building and repairing canoes on the beach. About 200 yards or so from the foot of the cliff a raised beach, of large water-worn coral boulders and a small quantity of sand, was crossed; it was about 5 feet higher than the land between it and the cliff, and a barometer-reading made the height above sea-level 60 feet.

"The land-upon which were growing some very large trees and thick undergrowth-from the raised beach to sea-level did not appear to be cultivated, and was thickly strewn with broken coral and large 
boulders, not so much vegetable mould being present among them as was the case nearer the foot of the cliff. The height of the tops of the trees on the highest part of the island, worked out by sextant angles from Gawa, gave the highest point as 520 feet above sea-level."

Kaileuna and Kirwina in the Trobriands are coral islands. Although both are for the most part low, the latter presents well-marked coral cliffs at its northern extremity. Beyond these to the west stretch a number of reefs and coral islands, the extent of which has not yet been accurately determined. Nada and Egum groups are atolls on which are a number of coral islands. In the centre of Egum atoll is the

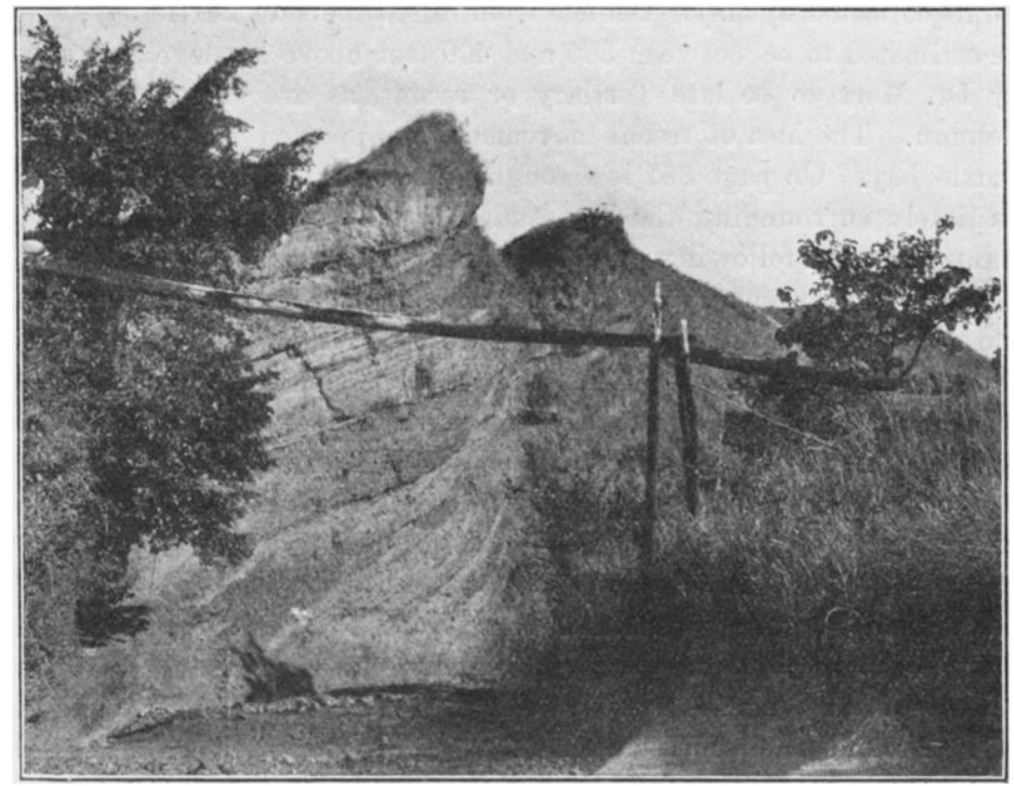

IRRIGATION AQUEDUCT, BARTLE BAY PLAIN.

island from which the group takes its name. At the northern extremity of Egum Sir George Ruthven le Hunte describes a rocky prominence "composed of bare rock with its strata lying at a vertical angle . . . and traversed

No raised coral reefs have as yet been reported on the D'Entrecasteaux archipelago, though these have been noted by $\mathrm{Mr}$. Gibb Maitland in the Loujsiades at Misima, Panaet, Wari, and Kimuta (about 10 miles east of Misima). On the mainland, the same authority notes raised reefs at Awaima, Bartle bay, and Cape Vogel; while on the south-eastern coast there is a raised reef on Einauro island, about 2 miles

* Annual Report, 1900-1901, p. 17. 
from Milport harbour. The distribution of the raised coral reefs just mentioned, and those previously referred to, are indicated in the sketch-map by dark areas or thickened outlines of the islands in which they occur. It will be seen that they indicate that a very large portion of British New Guinea has been uplifted.

The usual height above the present sea-level of the raised reefs in and around the south-eastern extremity of New Guinea varies from a few to 500 feet, but Mr. Gibb Maitland mentions a coralline limestone, called by the natives " korada," which forms a prominent object in the landscape at a height of 2000 feet up the mountain-side above Awaiama. He could detect no fossils in this. $\Lambda$ s regards the date of the uplift corals collected by Major Daniels from raised reefs at Bartle bay, which he estimated to be between 300 and 400 feet above sea-level, are stated by Dr. Marr to be late Tertiary or recent, as are those collected at Tohunu. The idea of recent movement is supported by the geology of Bartle bay. On page 351 is a rough sketch-map of the small area immediately surrounding the bay studied by Major Daniels, from whose manuscript the following notes are taken almost as they stand.

The country surrounding Bartle bay is, generally speaking, hilly and broken, without any striking preponderant mountains, hills, or valleys. The bay itself is a shallow indentation in the south coast of Goodenough bay, of roughly crescentic shape; the distance from horn to horn of the crescent being about 5 miles, and the general direction of a line joining the two being east and west. At the eastern extremity of the bay a hog-back hill rises abruptly from the sea to an estimated height of some 500 feet, and runs nearly south for 2 miles, then trending westward until, about $3 \frac{1}{2}$ miles from the coast in a direct line, it becomes broken, and ends rather suddenly at a point a little east of a north-and-south line drawn through the centre of the bay. Around the south-western foot of the Hogback a stream-the East river-debouches from the mountainous country inland on to the flat we call the Plain. Across this it takes a somewhat sinuous northward course to find the sea a little east of the bay's centre.

The sea-floor along the whole coast of the bay is extremely steep to, with no bottom in 30 fathoms half a cable length off shore. This beach itself is composed of water-worn pebbles. Behind this, except at the bay's extreme western limit, lies a remarkably level plain, which has already been alluded to as the Plain. For the most part the Plain joins the beach at the latter's horizon; but where the Plain's inequalities raise it above beach-level, the junction takes the form of low bluffs whose maximum height is never more than 12 feet. Here and there along the bay's coast, but always at some distance from the mouths of the East and Wamera rivers, a certain amount of coral is growing in the form of very narrow fringe reefs.

The eastern, and to a certain extent the south-eastern, boundary of 
the plain is the Hogback, which everywhere rises sharply from nearly level ground. On its extreme north-west the Plain ceases abruptly at the most eastern of a series of flat-topped plateaux, called in this paper the Terraces. These rise one after another, sometimes with slight intervening depressions towards the south-east, till they meet a range of broken hills which we call the Western hills, which have an estimated maximum height of 1000 feet. The T'erraces abut on the sea for about a mile, their slopes being so steep as to be nearly true cliffs, faced with a narrow beach. Beyond the Terraces' most western extension, the Western hills occupy the coast-line till the western limit of the bay is reached. The eastern boundary of the Terraces (where they abut on the P'lain) is of very irregular outline, and their southern limit does not reach more than $1 \frac{1}{2}$ to 2 miles from the coast in a north-and-south line, the western boundary of the Plain being taken up, after the Terraces cease, by a southerly and easterly extension of the Western hills. These hills then push south-east along the Plain's edge till, at a point a little west of the bay's centre and about 3 miles from the coast in a northand-south line, they swing more to the east, and move in that direction to the south-western end of the Hogback. The Plain, bounded as above described, is roughly triangular in shape, with the curved line of the bay's coast for its base.

Besides the Last river already mentioned, a second stream, the Wamera, debouches on to the Plain through the Western hills a little south of the southern limit of the Terraces, and, after skirting their eastern flank for a short distance, pursues a north-easterly course of considerable sinuosity, to find the sea about half a mile east of the most eastern terrace.

The Anglican mission station is located on the high ground in the angle formed by the eastern and coastal boundaries of the most eastern terrace.

The Plain.--The P'lain is both remarkably flat and level. The soil, usually very freo from gravel and stones, is of considerable depth nearly everywhere; and, under an admirable system of irrigation, yields excellent crops of sugar-cane, taro, etc. Below the soil, judging from such scant sections as the Wamera and East rivers have cut in the course of their passages, lie what appeared to be very definite layers of gravel or of sand, or of both mixed, sprinkled sometimes with rocks and even boulders, and with often a considerable proportion of mud, although there were found no distinct argillaceous strata.

After their debouchment on to the Plain, both the Wamera and East rivers occupy well-defined if shallow flood plains of considerable width.

The Terraces.-These formations, of which no visible counterpart exists along the eastern and southern boundaries of the Plain, rise for the most part very suddenly and steeply from the level ground, and with an even sweep except where the Wamera river or some gully 
has cut deeply into their sides. 'Their tops are remarkably level and even, and though the differences in horizon between the highest and lowest are not great, there is a steady upward progression of elevations from north-east to south-west. Where the Terraces abut on the sea, their slopes are even steeper than on the sides of the Plain, and gullies and slides are more frequent; while on the west they break away sharply and irregularly to a deep gulch, dry most of the year, which separates them on that side from the broken country of the Western hills. For the most part each succeeding terrace rises directly from the next lower in point of horizon; but where the width of the formation is considerably reduced by irregularities of outline, there is sometimes a shallow depression separating terrace from terrace.

The most south-western terrace, the highest in point of elevation, and estimated to reach a height of 150 to 200 feet, abuts, without any intervening depression, on a spur of the Western hills, which here become the western boundary of the Plain.

The Terraces are naturally treeless; the soil is thin and poor, very stony, and even rocky, and increasingly so as the junction with the Western hills is approached. Boulders are present here and there on the surfaces of the different Terraces.

Considerable opportunity is afforded in various places for viewing the internal structure of the Terraces, which would everywhere appear to be the same. The formation is completely stratified from top to bottom, the strata seldom more than 2 feet thick, and often not more than a few inches; the materials varying from stones and even boulders, nearly all much worn and rounded, down to gravel and fine sand, but without anywhere presenting any marked amount of strictly argillaceous matter. The strata are sometimes entirely, or almost entirely, composed of one or another material, but more frequently are much mixed; and none of them containing the coarser materials are sufficiently compacted to be called "stone," though some of the homogeneous strata of the finer materials appear as soft sandstone at all horizons from the top to the bottom of the different T'erraces.

The strata of which the Terraces are composed present the greatest disorder in the horizontal sequence of the different materials of which they are constituted, but wherever seen and at whatever horizon, they all dipped with great regularity to the north and north-east, and always at an angle which did not vary much from $30^{\circ}$.

It has already been stated that the 'Terraces abut on hills, which reach an elevation of about 1000 feet, and which we call the Western hills. As far as our inspection went, no stratified material was found on these bills above the level of the highest terrace, the range being composed of country rock, which Dr. Marr states is obviously volcanic and probably basalt.

The position of the raised coral reefs may now be stated. There is 
an ill-defined path leading over the Terraces from the mission station into the Western hills, and on through them to the villages on the coast of Goodenough bay to the westward. Immediately after leaving the level of the last terrace for the first slope of the hills, this path skirts a collection of coral masses. Below these masses, and on the terrace itself, are two or three coral boulders, evidently fallen from above, and below these coral fragments strew the terrace slope for many yards. Even the larger masses of coral are not now in situ at the (present) horizon of their original growth ; for elsewhere on the Western bills, both east and west of this point, long lines of coral can be seen at higher levels, which are constant enough to give ground for a presumption that the coral so appearing has not been much moved since the general uplift its presence above sea-level establishes. Near the masses of coral just mentioned, but slightly up the hillside and a little south, great solid sections of old reef-face have slid bodily down without breaking or uverending. Behind and above these lies the old reefsurface, covered with a thin layer of finely broken country rock so decomposed as to bear the usual scanty herbage. Above this, again, but only after a wide stretch of pure country rock, the old reef-surface begins once more, naked and marvellously like, for all its weathering, the surface of a living fringe reef from which the tide has fallen. Just above this, i.e. at an estimated height of 350 to 400 feet above sea-level, the level is reached (approximately) of the highest line of coral seen, and above this nothing but country rock was to be found.

Such is the present condition of the uplifted coral at the only point which press of other work permitted to be closely examined; at a point where-and the locality was chosen partly because this fact could be plainly established with the binoculars from the mission station-it has suffered the greatest displacement from its original position relative to the hillside. But it was impossible at this point (or elsewhere from such observations as could be made with the binoculars) to establish the vertical depth of the original growth of the reef with any accuracy, though it seems certain that this depth could not have been more than 40 or less than 30 feet.

The coral in situ, or nearly in situ, on the west side of the Plain is limited to the Western hills, lying west of the Wamera, and is not even visibly continuous on them at all points where it might be expected to appear. And although it was most carefully searched for, no trace of coral in any position or condition was found or seen $(a)$ on the Western hills lying between the Wamera and the East river, $(b)$ on the Terraces (with the exception of the fragments already alluded to), (c) on the Plain, or (d) in the beds of either the Wamera or the East river at any point of their course which came under our observation.

East of the Plain the coral appears here and there (but not con- 
tinuously to the eye) on the Hogback, at what must be very nearly the same horizon occupied by the coral in situ on the Western hills.

The foregoing account of the geomorphological features of Bartle bay has been given at some length, since it seems to bear on the age of the present coastal zone, and to suggest that the existence of Bartle bay in anything approaching its present form is a comparatively recent event. Dr. Marr, who has read through Major Daniels' notes on Bartle bay, and examined the photographs with which they are illustrated, suggests that the history of the coastal zone at this point is somewhat as follows : There was first a period of subsidence; when this occurred or how long it lasted is quite uncertain, but if the deposition of the reef rocks now upraised marked the closing stage of this depression, this stage was geologically recent, and probably there was no long period before elevation began. When elevation did take place, the coral reefs which had grown during the period of submersion on the flanks of the mountains were lifted to varying heights in different localities not very far apart. The movement was, in fact, in part differential. Further, it may well have occurred in stages. The evidence in favour of this point of view derived from the coral terraces of the Marshall Bennet group and the signs of surf action high up the cliff at Tokunu seems strengthened by the irregular nature of the stratification (current bedding) of the Bartle bay plain and the occurrence of the Terraces. The latter, Dr. Marr suggests, are the remains of old flood plains.

The fertility of the Bartle bay plain has already been alluded to. Roughly, three-quarters of its area is under cultivation at one time or another, and that portion is carefully irrigated from which a crop is to be taken. The southern portion of the Plain-the apex of the triangle -is irrigated from the East river. The intake of the main canal is about a quarter of a mile in a direct line from the nearest of the gardens, but, by reason of the lay of the land, the canal has to travel a good mile around the spurs of three hills, and across a gully (dry except at the height of the rains) some 70 feet wide by 40 deep, before it reaches the first lateral ditch. For this latter purpose an aqueduct of three hollowed logs is used. These are supported by both banks of the gully and two sets of uprights, each log so placed that it slightly underlaps the next preceding and is enough below it to make the path of the water a series of tiny cascades.

The northern portion of the plain is irrigated from the Wamera river, the intake of the canal being located a little below the point of the river's debouchment on to the plain. The canal in this case follows an uneventful course, without hills to circumvent or gullies to cross. Both the East river and the Wamera carry a considerable volume of water, even at the height of the dry season, while heavy floods are said to be, and on the evidence of erosion would appear to be, frequent in the wet season. 'The dams, therefore, which, in order to give an artificial 
head of water, are built across stream immediately below every intake, must be low enough to permit easy repair, and even easy reconstruction in case they are destroyed outright. All intakes are consequently located where the rivers are shallow, in spite of their greater width, where such is the case. The dams, which are made of water-worn boulders and stones, none larger than can readily be put in place by hand, piled loosely, so that the surplus water may.easily escape through their interstices, and are never more than about 3 feet high, though they may run to quite 100 yards in length. When necessary, turf and brushwood are used to render the dams less permeable.

The main canals are simply ditches, seldom more than 5 feet wide, and often less, and a foot or 18 inches deep. We neither saw nor heard of any case in which artificial banks had been made to conduct water across the surface of the ground. The laterals are simply the same thing reduced to scale, and there are nowhere any hatches or flumes of wood, nor any aqueducts (except in the case mentioned above, where the canal from the East river crosses the gully). But the results are sufficiently creditable, if not indeed actually marvellous, when it is considered that they were conceived with no more knowledge of engineering than a practical appreciation of the fact that water runs downhill, planned without the aid of any instruments for ascertaining or correcting levels, and executed with no better tools than the workmen's digging-sticks and hands.*

Before the paper, the President : Dr. Seligmann, whose paper we are to hear and discuss to-night, is not appearing on the platform of the Royal Geographical Society for the first time. I dare say some of you present may remember that five years ago Dr. Haddon, whom I am glad to see here to-night, read a very interesting paper on the Torres Strait, Dr. Haddon having gone out there on behalf of the University of Cambridge. One of the members of Dr. Haddon's expedition was Dr. Seligmann, and those who were present that night may remember that on that occasion he added some interesting remarks to Dr. Haddon's paper. Dr. Seligmann has the advantage, in studying anthropology, of being a member of the medical profession. Since the time of which I have been speaking, he has travelled extensively in British New Guinea, and he will now give us the benefit of his investigations there. He is going to introduce what, $I$ believe, is a novelty here-he is going to illustrate his lecture by means of the biograph, which, I am sure, will interest you. I now call upon Dr. Seligmann to read his paper.

After the paper, Dr. A. C. Haddon : It is with peculiar pleasure that I have followed this expedition of Major Daniels to New Guinea. Dr. Seligmann accompanied, as our President has said, the Cambridge Expedition to New Guinea in 1898-99, and he was one of the keenest and certainly the most versatile of my colleagues. Major Daniels, who had travelled a good deal in America, organized this successful expedition with Dr. Seligmann. They came to Cambridge for some months, and they thoroughly prepared themselves for their work, and the expedition was one of the best equipped that has ever left Europe. The credit of it, I may say, is due, in the first place, to the enthusiasm and the knowledge of Dr.

\footnotetext{
* Erratom.-Page 233, line 12 from top, for "west " read " east."
} 